\title{
Naar preventie op maat
}

\author{
Citation for published version (APA):
}

van Ree, J. W. (1990). Naar preventie op maat. Maastricht University. https://doi.org/10.26481/spe.19900928jr

Document status and date:

Published: 28/09/1990

DOI:

10.26481/spe.19900928jr

Document Version:

Publisher's PDF, also known as Version of record

\section{Please check the document version of this publication:}

- A submitted manuscript is the version of the article upon submission and before peer-review. There can be important differences between the submitted version and the official published version of record.

People interested in the research are advised to contact the author for the final version of the publication, or visit the DOI to the publisher's website.

- The final author version and the galley proof are versions of the publication after peer review.

- The final published version features the final layout of the paper including the volume, issue and page numbers.

Link to publication

\footnotetext{
General rights rights.

- You may freely distribute the URL identifying the publication in the public portal. please follow below link for the End User Agreement:

www.umlib.nl/taverne-license

Take down policy

If you believe that this document breaches copyright please contact us at:

repository@maastrichtuniversity.nl

providing details and we will investigate your claim.
}

Copyright and moral rights for the publications made accessible in the public portal are retained by the authors and/or other copyright owners and it is a condition of accessing publications that users recognise and abide by the legal requirements associated with these

- Users may download and print one copy of any publication from the public portal for the purpose of private study or research.

- You may not further distribute the material or use it for any profit-making activity or commercial gain

If the publication is distributed under the terms of Article $25 \mathrm{fa}$ of the Dutch Copyright Act, indicated by the "Taverne" license above, 
CIP-GEGEVENS KONINKLIJKE BIBLIOTHEEK, DEN HAAG

Roe, J.W. van

Naar preventie op maat / J.W. van Ree. - Maastricht :

UniversitairePers Maastricht

Met lit. opg., reg.

ISBN 90-5278-009-9

SISO 601.6 UDC 659.21613/614 NUGI 735

Trefw: huisartsgeneeskunde, hart-vaatziekten, pisico, diagnostiek. 
Een huisarts

is iemand die gekozen heeft

voor mensen.

Hij helpt hen en staat hen bij

in moeilijke, püjnlijke situaties

met zijn hart

en met zijn kennis.

Hij ziet achter schijnbare futiliteiten

angst.

zorgen

leegte

zodat zijn begrijpen

een houvast kan zijn voor de ander

om verder te gaan.

Een huisarts is een vriend

aan wie veel verteld kan worden.

Hij wordt dan deelgenoot

van de diepste vreugde en

het meest intense, vaak verborgen, verdriet.

Hij wordt mild

omdat hij in ieder ander

zichzelf herkent:

"de mens".

R.1990 


\title{
NAAR PREVENTIE OP MAAT.
}

\section{REDE}

\author{
uitgesproken bij de aanvaarding \\ wan het ambt van Hoogleraar \\ in de Huisartsgeneeskunde \\ aan de Faculteit der Geneeskunde \\ van de Rijksuniversiteit Limburg. \\ te Maastricht \\ op 28 september 1990 .
}

door Dr. J.W. van Ree 
Mijnheer de Rector, dames en heren toehoorders.

Dat zich binnen relatief korte tijd aan deze Universiteit opnieuw een Hoogleraar in de Huisartsgeneeskunde met een intree-rede aankondigt is niet zo opmerkelijk als dat op het eerste gezicht lijkt. Enerzijds wijst dat namelijk op het doorzetten van het proces van verjonging van het kader van de wakgroep Huisartsgeneeskunde, anderzijds geeft dat ook de brede taak en belangrijke plats aan die de vakgroep Huisartsgeneeskunde binnen deze Universiteit en Medische Faculteit inneemt. Ook wordt hiermee nog eens duidelijk geaccentueerd dat de Eerste Lijns Geneeskunde binnen deze Faculteit duidelijk herkenbaar moet zijn, zowel in het onderwijs als in het wetenschappelijk onderzoek. De uitgangspunten van deze faculteit worden ook bestuurlijk dus niet alleen met de mond beleden. De kracht van deze faculteit wordt in essentie bepaald door de mate waarop zij in staat is integratie te bewerkstelligen van academisch-klinisch met huisartsgeneeskundig onderzoek, onderwijs en patientenzorg.

Ik kan mij nog goed herinneren dat ik ruim 20 jaar geleden als onervaren huisarts mijn loopbaan startte. Ook kan ik me nog, alsof het gisteren was, herinneren dat ik mij inschreef voor een studie die mij fascineerde. Als arts zou ik de ideale combinatie kunnen vinden van de medisch-biologische en psychosociale kant van de mens. In mijn geheugen gegrift is het moment waarop Professor Frans Huygen mij in 1971 vroeg om mee te werken aan de opbouw van het opgestarte Instituut Huisartsgeneeskundle te Nijmegen. Toen hij mij in 1976 vroeg het Nijmeegs Interventie Project op te zetten, te leiden en op dit onderzoek te promoveren wist ik niet waartoe mij dat zou voeren.

In de afgelopen maanden probeerde ik mij een beeld te vormen van de wijze waarop ik mij als Hoogleraar Huisartsgeneeskunde zou kunnen inzetten voor deze medische faculteit en voor deze vakgroep.

Voor mij is het duidelijk dat dit in feite het vervolg moet zijn van de weg die ik indertijd ben ingeslagen.

Ik zie mijn taak dan ook allereerst bepaald door de kennis en ervaring die ik in de afgelopen jaren als praktiserend huisarts en als wetenschappelijk onderzoeker in de huisartsgeneeskunde heb opgedaan.

En dat, zowel het rationele als het emotionele van mijn huisartsenvak, wil ik zo goed mogelijk overdragen aan medische studenten en aan de huisartsen in opleiding. 
In dit eerste openbare college wil ik ingalan op enkele punten die natr mijn ervaring wan groot belang zijn voor verdere ontwikkeling van de huisartsgeneeskunde en, met name de ontwikkelingen op het gebied van de preventiewe patientenzorg.

\section{Aanbod van klachten.}

Wat mij als huisarts vanaf het begin heeft getroffen is de enorme gevarieerdheid aan klachten die ik tijdens ieder spreekuur weer tegenkwam. ledere dag was het opnieuw mogelijk dat ik woor een probleem werd geplaatst wat ik nog niet eerder was tegengekomen. Well kon er bijvoorbeeld afhankelijk van het jaargetijde in dit aanbod een bepaald accent liggen, maar steeds weer bleef dat gevarieerde aanbod van klachten mijn taak als huisarts bepalen. De huisarts moet tijdens hetzelfde spreekuur omgaan met acute afwijkingen, chronische ziekten, maar ook met nerveus funktionele klachten.

Typisch voor de huisartssituatie is ook, dat in hetzelfde consult, tegelijkertijd verschillende klachten worden aangeboden. Dit in tegenstelling tot de situatie van de specialist, die meestal slechts een voor zijn vakgebied specifieke klacht aangeboden krijgt.

Deze diversiteit van aangeboden klachten aan de huisarts komt uitdrukkelijk natr voren in het onlangs gerapporteerde nationale onderzoek wan het Nederlandse Instituut voor onderzoek in de eerste lijn (NIVEL) (1). Reeds eerder was gedemonstreerd in morbiditeitsregistraties in Nederlandse huisartspraktijken dat de gepresenteerde klachten vaak betrekking hebben op z.g.self-limiting diseases en dat ernstige afwijkingen relatief zelden voorkomen $(2,3)$.

Het zal een ieder die inzicht heeft in de huisartsgeneeskunde duidelijk zijn, dat het zeer moeilijk is in het geheel van klachten die klacht te detecteren, die verwijst naar nog niet overte, maar potentieel wel ernstige pathologie of die klacht aan te pakken, die ook in de ogen van de patient de belangrijkste klacht is. ledere keer zal de gepresenteerde klacht op zijn betekenis moeten worden beoordeeld.

Uit de gegevens zoals die zijn verkregen door ons eigen netwerk van registrerende Juisartspraktijken wordt duidelijk dat de huisarts, naast het omgatun met het dagelijks aangeboden pakket klachten, in zijn praktijk en dat over vakk lange tijd, ook zorg moet werlenen aan een grote groep vaak chronische patienten met een grote verscheidenheid aan klachten en ziekten (4).

Deze registraties bevestigen dat de hisavts een specialist moet zijn in frequent 
voorkomende "gewone" ziekten.

Vooral op basis van kennis van wat "nomaal" is moet hij de emst en betckenis van een klacht afwegen. De huisartis moet daarbij goed inzicht hebben in het spontane beloop van ziekten en hij zal moeten weten of de ziekte in potentie invaliderend is en wat de kans is op genezing of verergering. Door kennis hiervan anticipeert hij op komende ontwikkelingen en kan hij zijn adviezen daarop afstemmen.

De factor tijd speelt in de huisartsgeneeskunde een zeer belangrijke rol, zowel in het diagnostische als in het therapeutische proces.

Hoge eisen worden gesteld aan het persoonlijk funktioneren en psycho-sociale vaardigheden van de huisarts. Hoewel de patient meestal met een medisch getinte klacht bij de huisarts komt, zal de huisarts de patient niet steeds alls medicus kunnen en willen benaderen. Voor veel patienten heeft de huisarts niet alleen een funktie als medicus maar ook is hij raadgever en begeleider. Soms is de huisarts alleen maar verwijzer of wegwijzer in onze complexe medische en sociaal-maatschappelijke zorgstructuur. Niet zelden is de huisarts de beschermer van de patient tegen overbodige en soms zelfs schadelijke medische bemoeienis. Soms zal hij de patient tegen zichzelf trachten te beschermen. Af en toe zal de patient vragen om bescherming.

Het zall duidelijk zijn dat "preventie" binnen dit complex van taken van de huisarts een bijzondere plaats inneemt. Het gaat bij preventie immers over ziekten die er nog niet zijn bij patienten die meestal géén klachten hebben.

\section{Continuiteit in zorg.}

Zeer specifiek en essentieel in het huisartsenvak is het continue karakter van de patientenzorg (5). De huisarts ziet de patient gedurende diens levensloop meerdere keren en hij ziet de patient altijd in het kader van diens persoonlijke levenssfeer. Juist door die herhaalde contacten krijgen schijnbaar los van elkaar staande klachten een samenhangende betekenis (6).

Ook diagnostische processen vinden in de huisartsgeneeskunde vaak plats tijdens de herhalde contacten, en ook vastistelling van de prognose en instelling van een therapie of gerichte preventieve adviezen ontwikkelen zich vaak in de tijd.

Deze continue zorg heeft beslissende betekenis voor het uiteindelijke sukses van preventie en daarom hoort de huisarts bij preventie een vooratanstaande plaats in te nemen (7). 


\section{Preventie in de hussartspraktijk.}

Preventieve activiteiten behoren tot het dagelijkse werk van de huisarts. Niet alleen af op somatisch gebied maar evenzeer op psychosocialal gebied.

Niet werwonderlijk is dan ook dat een aanzienlijk deel van het onderzoek in de huisartsgeneeskunde gericht op "preventie" en met name op "preventie van hart en vaatziekten".

De basis van de nu bestaande preventieve zorg op het gebied wan hart- en valatiekten is, dat een verband kan worden aangegeven tussen een bepaalde eigenschap of kombinatie van werschillende eigenschappen bij een persoon en de kans op het optreden van afwijkingen in de toekomst.

Op basis hiervan kunnen risicogroepen worden gedefinieerd. Door vergelijking van groepen met en zonder een bepaalde risicoindikator kunnen relatieve risico "s worden berekend. Dat wil zeggen dat de kans wordt aangegeven in hoeverre de groep met een bepaalde eigenschap meer risico loopt dan de groep zonder. Zo worden verschillen in risico tussen groepen duidelijk gemaakt. Men gaat ervan uit dat het elimineren van dit op groepsniveau vastgestelde risico bij individuen uit $20^{\prime} n$ groep, positieve preventieve effecten heeft.

De huisarts speelt bij de uitvoering van de preventieve adviezen de belangrijkste rol ( 8 ).

Toch moet vastgesteld worden geworden dat de Nederlandse huisarts preventie niet systematisch is gaan toepassen bij die groepen die op basis van bovengenoemd onderzoek behoren tot de risicodragers.

Daar moeten toch belangrijke redenen voor zijn.

In de discussie over preventie van hart- en vaatziekten in de huisartspraktijk spelen voortdurend enkele punten een rol.

Deze discussiepunten zijn kort aan te geven met de woorden:

"uitwoerbaarheid in de praktijk", "gevaar voor somatische fixatie" en "preventieparadox" (9).

En zonder twijfel zijn dit ook reele problemen bij preventie, niet alleen op het gebied vin preventie van hart en vatziekten.

In hoeverre zijn cleze reele problemen oplosbaar? Om preventie werkelijk van de grond te krijgen is oplossing hiervan nodig, want de ontwikkeling van een preventief beleid bevindt zich door de steeds terugkerende discussie over deze punten in een ernstige impasse.

Naar mijn mening wordt "somatische fixatie" voor het belangrijkste deel veroorzaakt door een falende hulpverlening.

Gebrek aan kennüs van zaken zal een verkeerd beeld geven van de van 
preventie te verwachten effecten.

Gebrek ann kennis op diagnostisch gebied zal leiden to verkeerde indikatiestelling voor interventie. Het ontbreken van woldoende kennis wan therapeutische mogelijkheden zal leiden tot een verkeerde verwijzing of een onterechte all of niet medicamenteuze therapie. Een fallende patientenvoorlichting versterkt het proces van de somatische fixatie. Het ontbreken wan de juiste methode om preventieve principes te vertalen in verantwoorde adviezen en die op de juiste manier over te brengen, werkt somatische fixatie in de hand.

Problemen bij de "witvoerbaarheid" vragen om oplossingen op praktijkorganisatorisch vlak. Samenwerking, voldoende hulppersoneel, probleem georienteerde patientenadministratie, monitoringsmethoden, al of niet geautomatiseerd (10), zijn voorgestelde maatregelen om uitroerbaarheidsproblemen op te lossen.

\section{Praktijkorganisatie.}

Naast medische deskundigheid moet voor de huisarts ook het organisatorische aspect van de huisartspraktijk een belangrijk onderwerp van aandacht zijn.

Ik ben van mening dat het voor de toekomst van de huisarts een beslissend punt is of hij in staat zal zijn de zorgverlening in zijn praktijk te organiseren. Dat wi] zeggen dat hij de praktijkwoering dusdanig zal struktureren, dat hij het dagelijkse aambod van klachten zal kunnen overzien en beheersen, maar ook continue zorg woor chronische patienten en preventieve zorg, vaak gedurende vele jaren nodig, kan organiseren.

Is de specialist ingebed in de ziekenhuisorganisatie die er voor bedoeld is dat de "witte motor" zo goed mogelijk draait en die daarom vanzelfsprekend ook zal zorgen voor een organisatorische basisstruktuur (11), de huisarts zal acute zorg., chronische zorg, preventieve zorg, thuiszorg, surveillerende zorg zelf in zijn praktijk moeten organiseren.

Tot nu toe draaien praktijken hoofdzakelijk op de "motor" van de zich aanbiedende patientenstroom. Duidelijk moet worden gesteld dat dit inherent is aan de positie van de huisartspraktijk maar er moet een ontwikkeling plaatsvinden naar cen meer beheersmatige struktuur. Dit zal een aanzienlijke verandering in het management van de praktijkvoering tot gevolg hebben. Dan kan beter gerichte en georganiseerde aandacht worden geschonken aan specifieke patienten zowel curatief als preventief. 


\section{Consulentes voor de huisartspraktijk.}

Steeds duidelijker komt ndar woren dat voor een optimale preventieve zorgverlening een systematische praktijkorganisatie en -administratie noodzakelijk is (12). Het blikt dat huisartsen zeer goed in staat zijn bepaalde specifieke preventieve programma's uit te voeren, maar dan wel op voorwaarde dat hen ook geleerd wordt op welke wijze dit in de praktijk moet worden uitgevoerd $(13,14)$.

Een belangrijke ontwikkeling op praktijkvoeringsgebied bouwt hierop voort. Bimnenkort kunnen gegevens bekend worden uit een onderzoek naar de mogelijkheid om een nieuwe funktionaris in de Nederlandse huisartspraktijk te introduceren, namelijk de "praktijkconsulente" (15).

De invoering van zo $n$ worm wan hulpwerlening aan de huisans moet prioriteit hebben bij het streven naar $k$ walliteitsbevordering in de huisartsgeneeskunde. De grote moeite die veel huisartsen hebben met verwerking van het grote gevarieerde klachtenaanbod en het op basis hiervan verlenen van adequate, op maat gesneden, zorg kan anders leiden tot afbrokkeling van de huisartsgeneeskunde. Er is geen sprake van dat belangrijk gebrek aan kennis op preventief gebied de oorzaak is van de beperkte, nietsystematische inspanning van huisartsen op dit gebied; wel hebben velen grote moeite met de integratie van de kennis en kunde in een georganiseerde struktuur.

\section{Samenwerking in de praktijk.}

Essentiee $\|$ voor optimalisering van de huisartsgeneeskundige patientenzorg is de samenwerking met de doktersassistente. Voor de op korte termijn gewenste professionalisering van de praktijkorganisatie is de verdere uitbouw van de takak van de doktersassistente noodzakelijk.

In het Nijmeegs Interventie Project is de grote waarde van de doktersassistente angetoond voor het uitvoeren van een preventief programma op het gebied van hart-en vatziekten $(16,17)$. Sindsdien is haar taak vaak onderwerp wan onderzock geweest $(18,19)$.

Hieruit komt natar voren dat de doktersassistente een nauweljiks te onderschatten ondersteunende rol kan spelen bij de gewenste optimalisering vatu de patientenzorg.

Een belangrijke tatk zal zijn weggelegd op het praktijk-orgunisatorische gebied. De uibouw van de taak van de doktersassistente heeft prioriteit bij $k$ waliteisbevordering in de huisartsgeneeskunde $(20)$.

Het is noodzakelijk dat verantwoordelijke instanties de uitbouw van deze taak 
op zeer korte termijn ter hand nemen.

\section{Kosten-effectiviteits onderzoek.}

Om inzicht te krijgen in uitwoerbaarheid moeten huisartsen onderzoeken op welke wijze specifieke nieuwe preventieve taken op de beste manier in de praktijk kunnen worden toegepast.

Bij iedere nieuwe taak, ook als die niet ligt op het gebied van preventie hoort trouwens een nauwkeurige beschrijving van het "hoe".

Bij dit implementatie onderzoek moet gekeken worden naar bedrijfsmatige uitvoerbaarheid en naar de positieve en negatieve effecten van preventieve programma"s. Feitelijke uitvoering wan een dergelijk programma en daarmee de effectiviteit wordt voor het grootste deel bepaald door de haalbaarheid in de praktijk.

In de huisartspraktijk moet in toenemende mate kosten-effectiviteitsonderzoek worden uitgevoerd om inzicht te krijgen in bovengenoemde aspecten.

\section{Gediffentieerde risicoschatting.}

Het laatste genoemde probleem is de "preventieparadox". Hierbij is sprake van het paradoxale verschijnsel dat wat voor een groep geldt niet bij voorbaat ook voor een individu geldit.

De belangrijkste vraag in dit kader is of het mogelijk is om de individuele patient met voldoende zekerheid te kunnen zeggen, dat de vaak niet geringe preventieve inspanningen voor hem of haar zeker de moeite waard zullen zijn. Om deze zekerheid te kunnen bereiken moeten de juiste personen worden geidentificeerd namelijk die personen waarvan we uit onderzoek weten of we op redelijke gronden mogen aannemen dat preventie op relatief korte termijn effect heeft $(21,22,23,24,25,26,27,28,29,30,31)$.

De nieuwe vragen die nu naar voren komen zijn ook niet gemakkelijk te beantwoorden.

Hoe moeten die personen uit deze specifieke groep dan worden geidentificeerd?

Hoe moet daarvoor het diagnostische proces verlopen, hoe dient het preventieve advies te luiden en hoe moet een dergelijke patient, vaak over jaren, worden vervolgd?

Door antwoorden te vinden op deze vragen wordt het mogelijk de discussie 
over de "preventieparadox" te beeindigen en de ontwikkeling van preventie in de huisartspraktijk wit de impasse te halen.

Bij ieder individu tal een vaak een unieke set van "variabelen" aan de orde zijn. Dit vraagt naar een specifieke afweging van kosten en baten, met intchtneming van alle negatieve aspecten.

\section{Geindividualiseerde patientenxorg.}

Deze wijze van geindividualiseerde risicovaststelling, door mij liever "gedifferentieerde risicoschating" genoemd, sluit veel beter aan bij het zorgmodel van de huisarts.

De op de individuele patientenzorg gerichte aandacht van de huisarts komt vala in de knoop met de huidige, algemene preventieve aanbevelingen.

Hoewel er in de praktijk een groep diabetes patienten is aan te wijzen, een groep hypertensiepatienten, een groep patienten met een hartinfarct, is de zorg van de huisarts in werkelijkheid gericht op de oudere, matig adipeuze patiente met lichte diabetes en lichte hypertensie, moeder van acht getrouwde kinderen die zo gezellig vaak op bezoek komen, en op de adipeuze zakenman met lichte hypertensie of op de postinfarct-patient die depressief uit het ziekenhuis thuiskomt. Er bestaat binnen de groep hypertensiepatienten op individueel niveau zo'n spreiding van de mate van risico dat de ene hypertensiepatient niet zo maar met de ander kan worden vergeleken. Zo is bijwoorbeeld duidelijk geworden dat vrouwen zonder verdere cardiovasculaire risicofactoren zelden woor verhoogde bloeddruk moeten worden behandeld.

Zo heeft een hypertensiepatient met tekenen van (beginnend) Linker Ventrikel Hypertrofie een zeer aanzienlijk hoger sterfterisico, dan een vergelijkbare persoon zonder Linker Ventrikel Hypertrofie $(21,23)$.

Zo weet de huisarts dat de ene diabetes patient qua risico de andere niet is. Hij ziet met vorbazing dat tussen diabetespatienten, die schijnbaar niet van elkatr te onderscheiden zijn, soms enorme verschillen ontstaan in de ontwikkeling van vasculare complicaties. Dat betekent dat per individu gezocht moet worden natr symptomen wardoor de patient in een geheel andere risicogroep moet worden geplatst $(22,25,29)$.

Hypertensie en verhoogd cardiovasculair risico komen vaak in families voor en de huisarts zal leden uit die fumilies anders moeten benaderen dan de nerveuze huismoeder met geringe bloeddrukverhoging, die juist voor het spreekuurbezoek haur kinderen in haast naar school heeft gebracht. 
In plats van zijn energie en tijd te stoppen in de behandeling van de grote groep patienten met geringe bloeddrukverhoging warbij van behandeling op individueel niveau weinig winst is te verwachten, moet de huisarts bij patienten het risico gedifferentieerd vaststellen on die patienten te kunnen selecteren die baat hebben van de preventieve adviezen of behandeling.

De taak van de huisarts wordt daar nier makkelijker door. Voor het nauwkeurig inschatten wan het risico van een individu op basis van een anntal gegevens uit anamnese en onderzoek is systematisch handelen nodig.

Het is duidelijk dat een dergelijke PREVENTIE OP MAAT hoge eisen stelt aan de medische kennis en kunde van de huisarts, aan de nawkeurigheid van het diagnostisch proces en aan de kennis wan theropeutische mogelijkheden.

Nauwkeurige risicoschatting voorkomt ook ongewenste medicalisering. De huisarts kan zijn patient beschermen tegen onnodige zorg door de aandacht te richten op die patienten die meer zorg dan andere nodig hebben.

\section{Optimalisering van diagnostiek.}

Gedifferentieerde risicoschatting is een diagnostisch proces.

Hoewel de ziekten in de huisartspraktijk meestal "eenvoudige ziekten" lijken is juist in het kader van de huisartspraktijk diagnostiek een proces dat veel zorgvuldigheid vraagt.

Bij het stellen van een diagnose bestatat altijd de kans dat deze ten onrechte wordt gesteld. Of omdat de meting niet deugde door falen wan het meetinstrument of van degene die de meting uitvoerde of gewoon omdat toevallig op dat moment bij de patient de te meten variabele afwijkend was, terwijl dit klinisch van geen belang was.

In de huisartspraktijk zijn de waarneembare afwijkingen meestal gering en vaker is een schijnbaar afwijkende meetwaarde toch een variant van nomal of een toevalligheid. Om te voorkomen dat iemand ten onrechte als ziek of als risicopatient wordt geklassificeerd, moeten diagnoses met alle mogelijke zorgvuldigheid worden gesteld.

Omdat de voorspellende waarde van een diagnostische tests in een populatie het best geschat kan worden als die test ook binnen die populatie ontwikkeld is, behoren de meeste bestaande testen door de huisarts met de nodige woorzichtigheid worden toegepast $(32,33)$.

Daar de factor tijd belangrijk is in het beloop van een biologische eigenschap, moet ook dit worden betrokken bij het stellen van een diagnose. Voorts is 
variabiliteit wan biologische eigenschappen individueel bepatald en ook deze individualiteit moet bij iedere diagnosestelling worden meegewogen.

In veel gevallen kan voor een diagnose stelling niet volstaan kan worden met een erkele meting.

De ontwikkeling vain de diagnostiek in de huisartspraktijk moet dan ook veeleer gaan in de richting van het ontwikkelen van diagnostische procedures.

Een woorbeeld is de diagnosestelling "hypertensie". Deze is niet zo eenvoudig te stellen. Zo kumnen omstandigheden bij een persoon de bloeddruk omhoog jagen terwijl er geen sprake is van het bestaan van hypertensie (34). Zeker als de bloeddrukverhoging gering is vraagt de diagnosestelling een nauwkeurige procedure.

Voor de huisartspraktijk is ontwikkeling van toepasbare diagnostische procedures en op de individuele patient toegesneden vormen van zorgverlening op basis van gedifferentieerde risicoschatting nodig voor verbetering van de $k$ waliteit van de huisartsgeneeskundige medische zorg.

Zeker bij preventie waarbij er een precaire verhouding bestaat tussen inspanning en positieve en negatieve effecten is dit belangrijk.

\section{Onderwerpen voor onderzoek.}

Als we kijken thaar de preventieve taak van de huisarts en de behoefte aan betrouwbare diagnostische procedures op dit gebied dan zal het onderzoek in de huisartspraktijk zich in de komende jaren moeten richten op de volgende gebieden:

feasibility onderzoek van preventieve programma's en nauwkeurige analyse van positieve en negatieve aspecten van dergelijke programma's in de huisartspraktijk.

- onderzoek naar diagnostische procedures en ontwikkeling van voor de huisartsgeneeskundige toepasbare besliskundige regels.

In dit kader is onlangs een voor de huisartsgeneeskunde fundamenteel te noemen onderzoek gestart naar "optimalisering van hypertensie diagnostiek". Hoewel in eerste instantie gericht op "hypertensie", zijn uitkomsten van dit onderzoek ook van bellang voor andere risicofactoren zoals hypercholesterolaemie maar ook voor aandoeningen zoals diabetes mellitus en CARA. 
- onderzoek nar gedifferenticerde risicoschatting binnen groepen met verhoogd risico. Dit geeft de mogelijkheid om het accent wan inspanning bij behandeling te leggen bij die personen bij wie specifieke interventie een positieve kosten- en batenverhouding laat zien en waarschijnlijk reeds op korte termijn invloed zal hebben op morbiditeit en mortaliteit.

- $\quad$ onderzoek naar effecten van interventie bij vroege stadia van ziekteontwikkeling op morbiditeit en mortaliteit op konte en lange termijn. Uit een lopend onderzoek in een aantal huisartspraktijken blijkt dat bij een relatief hoog percentage van de hypertensiepatienten tekenen van linker wentrikel hypertrofie woorkont.

Onderzoeksgegevens uit de huisartspraktijk naar de betekenis van interventie voor ontwikkeling van morbiditeit en mortaliteit (35) bij deze patienten zijn mij niet bekend.

\section{Samenwerking bij onderzoek.}

Gezien het vroegdiagnostische en -therapeutische karakter van bovengenoemd onderzoek bij patienten uit de huisartspraktijk ligt het accent wan dit onderzoek binnen de huisartspraktijken. De bestaande raakvlakken met de klinische patientenzorg en -onderzoek maakt complementaire ondersteuning door specialisten en andere deskundigen noodzakelijk.

$\mathrm{Bij}$ hen is vaak al langer specifieke deskundigheid opgebouwd, die echter vaak bruikbaar gemaakt moet worden voor onderzoek in de op patientenzorg ingestelde huisartspraktijk.

Veel ziekten komen in de huisartspraktijk niet vaak voor. Daarom is het waak noodzakelijk om voldoende patienten te kunnen onderzoeken, meer huisartspraktijken bij onderzoeksprojecten zijn betrokken. Bij het huisartsgeneeskundig onderzoek moet datarom vaak multicentered onderzoek plaatsvinden.

Omdat een regio behorende tot een medische fuculteit een beperkt aantal huisartspraktijken omvat die op een bepaald moment een onderzoek kunnen of willen uitvoeren, zal het in toenemende mate nodig zijn dat de vakgroepen huisartsgeneeskunde van werschillende universiteiten samenwerken bij opzet en uitvoering van onderzoeksprojekten. In het hypertensieonderzoek van onze vakgroep wordt behalve met andere facultaire afdelingen ook samengewerkt met de vakgroep Huisartsgeneeskunde en de afdeling Interne Geneeskunde van de Nijmeegse Medische Faculteit. 
Mogelijk kan op den dur gekomen worden tot funktionele integratie van de onderzockprogramma's van beider afdelingen op cardiovasculair gebied. Tussen deze twee faculteiten bestaat trouwens reeds een samenwerkingsrelatie op het gebied van kwaliteitsbewordering in de huisartsgeneeskunde.

De bowenbeschreven ontwikkeling vraagt aanzienlijke versterking van het onderwijs en het onderzoek op dit gebied want ook deze ontwikkeling zal niet vanzelf gatu.

\section{Onderwijsstruktuur.}

Huisartsen moeten gezien het klachtenaanbod een uitgebreide kennis hebben op medisch gebied. Zij zijn immers degenen bij wie de patient in eerste instantie met een klacht binnenkomt. De huisarts zal de beslissing moeten nemen over de vraag in welk kader hij de klacht van de patient moet plaatsen. Ook de beschreven ontwikkeling op het gebied van preventie op mat vraagt om gedegen kennis op medisch-somatisch gebied waarbij de regels op het gebied van de besliskunde bekend moeten zijn.

De onderwijsstruktuur van deze faculteit maakt het ook mogelijk in het onderwijs aan studenten de gewenste integratie te bereiken tussen het patient gebonden, medisch-klinische aspect van de geneeskunde en wat wordt genoemd de basiswakken in de geneeskunde.

Inzicht in bio-fysiologische processen is nodig voor goed begrip van mogelijkheden en beperkingen van diagnostische en therapeutische procedures en van de achterliggende motieven en mechanismen. Besliskundige aanbevelingen die geldig zijn in de huisartsgeneeskundige situatie moeten hieruit volgen. Voor de ontwikkeling daarvan ligt een belangrijke taak bij deskundige huisartsen en deze kennis moet worden overgebracht aan studenten vanuit het perspectief van de huisartsgeneeskunde.

Dit vraagt om huisarts-docenten met huisartsgeneeskundig inzicht en wetenschappelijke kennis en ervaring, en om huisartsen die in staat zijn deze takk didactisch op zich te nemen. Ook binnen het praktisch medisch onderwijs in de huisartsgeneeskunde (pmo-H) moet dit het geval zijn.

Voor hen die huisarts worden krijgt de opleiding tot arts een vervolg binnen de beroepsopleiding. Dit is een belangrijke taak voor de vakgroep en ook voor de beroepsopleiding moet het bovengenoende gelden. Naast aandacht voor optimaliseren van de onderwijskundige kwaliteiten van de docent-opleiders moet scholing op medisch inhoudelijke vlak een punt van voortdurende 
aandacht zijn.

Omdat het praktisch medisch onderwijs in de huisartsgeneeskunde en de beroepsopleiding tot huisarts in elkaars verlengde liggen verdient het overweging de scholing van de huisartsdocenten van het praktisch medisch onderwijs en de beroepsopleiding op elkaar af te stemmen.

In toenemende mate is er sprake van dat de huisartsen in onze regio de medeverantwoordelijkheid voor de kwaliteit van de opleiding van hun a.s. collega's willen dragen. Daardoor ontstaat er vamuit de huisarts-docenten een steeds grotere vraag naar gerichte scholing op bovengenoemde gebieden. Dit is een belangrijke ontwikkeling die verder ondersteund en gestimuleerd dient te worden, zowel vanuit de vakgroep als vanuit de faculteit.

In het verlengde van de beroepsopleiding tot huisarts ligt het postacademiale onderwijs.

Deze vakgroep huisartsgeneeskunde kan niet alleen op de faculteit gericht zijn maar moet ook gericht zijn op de huisartsen in onze regio. De ondersteuning van het postacademiale onderwijs is een taak voor de vakgroep en in het verlengde hiervan voor de faculteit. Intensieve samenwerking met de regionale huisartsorganisatie op dit gebied is hiervoor nodig. De inbreng op inhoudelijk gebied staat hierbij voorop.

\section{Onderzoeksstruktuur.}

Omdat een belangrijk deel van de onderzoeksactiviteiten van de vakgroep zich moet afspelen in de "kliniek van de huisartsgeneeskunde" is verdere uitbouw van de samenwerking met de huisartsen in onze regio van groot belang. De onderzoekmogelijkheden van de vakgroep huisartsgeneeskunde wordt in sterke mate bepaald door de grootte van het onderzoeksveld en de ervaring die huisartsen hebben met het uitvoeren van onderzoek.

Onder andere uit eigen ervaring en uit inventariserend onderzoek door de vakgroep $(36,37)$ is duidelijk geworden dat het voor onderzoek in de huisartspraktijk erg belangrijk is dat huisartsen het onderwerp van de studie relevant vinden en in de praktijk goed uitwoerbaar is. Voor de halbatrheid is het nodig dat het onderzoeksdesign uitvoerbatar is en niet all te zeer interfereert met de reguliere patientenzorg.

Velle collega's, ook niet huisartsen zal dit niet onbekend in de oren klinken. 


\section{Dames en Heren,}

Ik heb geen, a] dan niet nieuwe, theorieen over de huisartsgeneeskunde gepresenteerd. Dat hebben al vele anderen gedaan. Bovendien, de funktie van de huisartsgeneeskunde ontwikkelt zich zo snel, zowel medisch inhoudelijk als maatschappelijk, dat theorieen van vandaag morgen verouderd kunnen zijn. Ik heb aangegeven waar, naar mijn mening, belangrijke ontwikkelingen gaan en moeten plaatsvinden op het gebied van onderzoek en onderwijs in de huisartsgeneeskunde.

De ontwikkelingen van de huisarts bevind zich naar mijn mening in de laatste fase van een professionaliseringsproces. De huisarts zal op basis van wetenschappelijke argumenten, in toenemende mate de vorm en inhoud gaan bepalen voor de eigen plakts en funktie in de gezondheidszorg. Professionalisering van het huisartsgeneeskundige klinische onderwijs door praktiserende huisartsen en ontwikkelen van ervaring met huisartsgeneeskundig onderzoek door praktiserende huisartsen zijn naar mijn mening de latste stappen in dit emancipatieproces.

Op allerlei manieren en steeds meer krijgt de samenwerking van deze vakgroep met de huisartsen in deze regio gestalte. Hiermee word gedemonstreerd dat deze huisartsen hun verantwoordelijkheid voor de toekomst wan hun vak hebben genomen.

Dat proces van professionalisering is wooral binnen deze Universiteit, binnen de vakgroep Huisartsgeneeskunde van deze Medische Faculteit, in een indruk wekkende stroomversnelling terecht gekomen.

Het is mij een grote eer als hoogleraar te kunnen meewerken aan het voltooien van dit proces.

Ik hoop van harte dat ik, samen met de medewerkers van de vakgroep Huisartsgeneeskunde aan deze taak kan werken.

Mijn gevoll voor verantwoordelijkheid voor onze gezamenlijke toekomst is door de bijzonder loyale en vriendelijke manier waarmee jullie mij ontvangen en opgevangen hebben extra gestimuleerd.

Tenslotte: Allen die een rol hebben gespeeld in het feit dat ik nu hier sta ben ik zeer erkentelijk.

Ik dank U voor Uw aanwezigheid en aandacht. 
Met dank aan André Knottnerus, Harry Crebolder "Vic Dubois en Jos op "it Root voor hun kritische kommentaar bij het manuscript. 


\section{Literatuur.}

1. Van der Velden J. Nationale Studie van ziekten en verrichtingen in de huisartspraktijk. Medisch Contact 1990; 45:605-11.

2. Van Weel C, Van den Bosch WJHM, Van den Hoogen HJM. De continue Morbiditeits Registratie Nijmegen. Huisarts \& Wetenschap $1986 ; 29: 373-7$.

3. Lamberts $H$. Aan de diagnose gebonden informatie uit de huisartspraktijk. Ned.Tijdschr.Geneesk. 1986; 130: 292-6.

4. Höppener P, Knotmerus JA, Metsemakers JFM, Kocken RJJ, Limonard ChBG. Het registratienet huisartspraktijken van de Rijksuniversiteit Limburg. Een geautomatiseerd steekproefbestand voor huisartsgeneeskundig onderzoek. Huisarts \& Wetenschap 1990; $33(2): 66-9$.

5. Grol R, Smits A, Franssen H. ea. Continuiteit in de huisartsgeneeskunde. Huisarts \& Wetenschap 1987; 30: $275-9$.

6. Huygen FJH. Family medicine. A medical life history of families. Nijmegen: Dekker \& vd Vegt, 1978.

7. KasI SV. A social-psychological perspective on succesfull community control of high bloodpressure: a review. J.Beh.Med.1978; 1(4): 34781.

8. Gezondheidsraad. Advies inzake epidemiologie en preventie van ischaemische hartziekten 1984. 's Gravenhage.

9. In dit kader is ook de diskussie te plaatsen die in 1987 plats vond in Medisch Contact naar aanleiding van de publikaties van Dr. C. Boot, huisarts te Wierden.

10. Van den Hoogen JPH, Van Ree JW. Preventive cardiology in general practice: computer-assisted hypertension care. J Human Hypertension. $1990 ; 4: 365-7$.

11. Veldhorst JF. Gezond management. Procesbeheer, organisatie en motivatie in de gezondheidszorg. Uitg: De Tijdstroom, Lochem, 1985.

12. Van Ree JW, Van Gerwen W, Van den Hoogen H. Interventie bij een verhoogd risico op hart en vaatziekten. I. Resultaten op langere termijn van interventie bij hypercholesterolaemie, adipositas en roken. Huisarts \& Wetenschap. 1985; 28: 21-4.

13. Van Ree JW, Rutten $G$, Van den Bosch WJGM. Praktijkmanagement en hypertensiebeleid. Huisarts \& Wetenschap. 1985; 28: 133-6.

14. Schraven D, Van Ree JW, Van Gerwen W, Van den Hoogen HJ. Het RIFOH projekt.NHG Utrecht- NUHI Nijmegen 1987. Gebaseerd op 
de conclusies van het RIFOH-project werd daama het Pre Tensie project uitgevoerd waarin een aantal Basis Gezondheids Diensten een. honderdtal huisartspraktijken ondersteunde bij het uitvoeren van een preventief programma. Het evaluatierapport door Drs. A.Drenthen (werkgroepleider: Prof.Dr. J.W. van Ree) zal einde 1990 werschijnen.

15. Zie in dit kader het onderzoeksprotokol wan het huisarts assistentie preventie project (HAPP) dat nu wordt uitgevoerd in de regio's Rotterdam en Nijmegen (Drs.H. van der Wouden,Drs.B. van Drenth, Drs.M. Conradi) met subsidie van de Nederlandse Hartstichting.

16. Van Ree JW. Het Nijmeegs Interventie Project. Proefscluift Nijmegen 1981.

17. Van Ree JW. Assistente en hypertensiebestrijding. Huisarts \& Wetenschap. 1983; 26: 49-53.

18. De Haan J. De doktersassistente. Delegeren van taken in een huisartspraktijk. Lelystad: Meditekst. 1986.

19. De Haan J. De rol van de assistente bij preventie in de huisartspraktijk. In: Medifo. Informatiegids voor de gezondheilszorg 5; 3: 11-3. Utrecht: Bohn, Scheltema \& Holkema, 1989.

20. Nijland A, De Haan J, Van der Velden J, Meyboom-de Jong B. De sociale en professionele kenmerken van de doktersassistente. Huisarts \& Wetenschap. 1990; 33(9): 350-4.

21. American Heart Association. Coronary risk handbook.

Estimating risk of coronary heart diseases in daily practice. New York, 1973.

22. Frolich ED. Cardiac hypertrophy in hypertension. N England J Med 1987; 31:831-3.

23. Kannel WB. Prewalence and natural history of electrocardiographic left wentricular hypertrophy. Am J Med 1983; 62:4-11.

24. Baron John A. The clinical utility of risk factor data. J Clin Epidemiol. 1989; 42(10): 1013-20.

25. Laupacis A, Sacket DL, Roberts RS. An assesment of clinically usefull measures of the consequences of treatment. N Engl J Med. $1988 ; 3.18(26): 1728-33$.

26. Van Ree JW, Van Weel C, Arts H, Van den Hoogen H. De samenhang tussen "transient ischaemic attack" en cerebrovasculair accident. Ned Tijdschr Geneesk 1989; 133(21): 1073-6.

27. Rosengren $\mathrm{A}$, Welin 1, Tsipogianni A, Wilhelmsen L. Impact of cardiovascular risk factors on coronary heart disease and mortality among middle aged diabetic men:a general population study. Br Med J $1989 ; 299: 1127-31$. 
28. Veterans Administration Cooperative Study Group on antihyperterisiwe agents. Effects of treatment on morbidity i hypertension. III. Influence of age, diastolic pressure and prior cardiovascular disease; further analysis of side effects. Circulation 1972; 45: 991-1004.

29. Collins R, Peto R, MacMahon S, ea. Bloodpressure, stroke, and coronary heart disease. Part 2 , short-term reduction in bloodpressure: an overview of randomised drug trials in their epidemiological context. Lancet 1990; 335: 827-38.

30. Hypertension-Stroke Cooperative Study Group. Effect of antihypertensive treatment on stroke recurrence. JAMA 1974; 229: 409-18.

31. Joint National Committee. The $₫ 988$ report of the joint national committee on detection, evaluation, and treatment of high bloodpressure. Arch Intern Med 1988; 148: 1023-38.

32. Knottnerus J.A. De betekenis van pijn op de borst voor de diagnostiek van coronaire hartziekte en myocardinfarct. Huisarts \& Wetenschap 1987; 30(suppl H\&P11): 46-51.

33. Van der Velden HGM. Diagnose of prognose. Betekenis van de epidemiologie voor het handelen van de huisarts. Huisarts \& Wetenschap $1983 ; 26: 125-8$.

34. Montfrans GA, Karemaker JM, Wreling W,e.o. Vergelijking van de bloeddrukmeting tijdens het spreekuur en door patienten zelf. Ned Tijdschr Geneesk. 1986; 130,23: 158-63.

35. Hier wordt verwezen naar het NWO-project: Hypertensie Monitoring in de Huisartspraktijk uitgevoerd door Drs.J.P.H. Van den Hoogen, huisarts. Werkgroepleider: Prof.Dr.J.W. Van Ree.

36. Stoffers HEJH, Kailser V. De uitwoering van patientgebonden aandoeningsgericht wetenschappelijk onderzoek in de

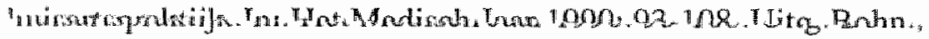
Scheltema \& Holkema, Utrecht 1990.

37. Prenger-Duchateau AMH, Kocken R. Op weg naar een betere samenwerking. Scriptieverslag huisartsopleiding Maastricht, 1989. 